\title{
A Kaleidoscopic Gaze of India through Julio Barrenechea's oeuvre
}

\author{
Mala Shikha ${ }^{1} \&$ Ranjeeva Ranjan ${ }^{2 *}$ \\ ${ }^{1}$ Assistant Professor, Doon University, Dehradun, India. maladoon@gmail.com \\ ${ }^{2 *}$ Assistant Professor, Universidad Católica del Maule, Talca, Chile. ranjan@ucm.cl
}

\begin{abstract}
Latin American intellectuals have included India in their imagination since the advent of Modernism, a turnof-the-century movement in the early 20th century. Nevertheless, the idea of India in Latin American imagination has been primarily mediated through a rather fixed European lens. Within the body of Latin American scholarly encounters, the works of Julio Barrenechea are worth mentioning. They have not been critically examined extensively in academia. The present study is an attempt to reflect upon the works of the author that resulted from his experiences during his sojourn as the Ambassador of Chile in India. He wrote Sol de la India, which was published in 1969 in New Delhi, during his stay in India. Another work titled La India no misteriosa based on his Indian experience was published posthumously in 1982 in Santiago. The first work is a collection of poems while the latter is in prose. Barrenechea has described with grace and sympathy the spiritual greatness of India but at the same time, he engaged critically with the distressing social and economic realities of the nation. In the present study, the researchers analyze the theme of his works encompassing India, which as such incorporate an essentially "Chilean gaze".
\end{abstract}

Keywords: Barrenechea, Chilean gaze, Sol de la India, La India no misteriosa, Kaleidoscope, European lens

\section{Introduction}

The scholarship on the Orient of Latin American intellectuals can be traced back to the turn-ofthe-century Modernist movement in the late $19^{\text {th }}$ century. Themes and motifs pertaining to the East or the Orient, and by extension India, have been included in works of Latin American authors like Rubén Darío whose collection "Medallones" (Azul, 1888) mentions of fakirs, rajahs, elephants etc. His desire to be cosmopolitan and go beyond the mundane depiction of 19th-century Realism drove his imagination to the East and India, and especially in his search of the exotic. Upon studying his engagement, one realizes that he drew inspirations from Europe, mainly from French literary movements such as Romanticism, Parnassianism and Symbolism in order to engage with the East. Rubén Darío never traveled to the East, but his engagement, especially with India, acts as a leading light for Latin American intellectuals who would travel to India and write about the country in the years to follow.

Nevertheless, following the leading lights of the Modernist movement, such as Dario's, this engagement with India becomes more graphic in the 20th century. There have been many Latin

This Open Access article is published under a Creative Commons Attribution Non-Commercial 4.0 International License (http://creativecommons.org/licenses/by-nc/4.0/), which permits non-commercial re-use, distribution, and reproduction in any medium, provided the original work is properly cited. For citation use the DOI. For commercial re-use, please contact editor@rupkatha.com. 
American intellectuals, some famous and some not so known, who visited India from time to time and documented their experiences. These works were based on their sojourn in various parts of India, in different capacities that ranged in contribution from essays to travel writings, fiction to poetry. Latin American ambassadors such as the Chileans Augusto D'Halmar and Miguel Serrano, and Mexican Octavio Paz who later won the Nobel Prize for literature (1990) may be mentioned as the most prominent figures. Some other names include an ambassador to India in recent times and Colombian short story writer Juan Alfredo Pinto Saavedra, and other occasional travelers to India such as the Cuban essayist Severo Sarduy, the New York-based Dominican dancer and educator Josefina Baez and poet, Rogelio Sinán, the Panamanian Consul to British India in 1938.

Gabriela Mistral, the first Latin American author to win Nobel Prize for Literature in 1945, came to know about India primarily through Tagore's works and looked at it as a land of nostalgia (Dey, 1971), although she never traveled to India. Another Nobel Laureate from Chile (1971), Pablo Neruda, arguably one of the most studied Latin American poets in India, came a step closer and traveled to present-day Kolkata on a diplomatic assignment in 1928. He seems to be thoroughly impressed by Tagore as is noticed in his early works like Veinte poemas de amor y una canción desesperada (1924). However, he confessed later that India did not influence him (Gómez, 2011). Augusto D'Halmar who was the Chilean Consul to British India in 1907 published the travelogue Nirvana (viajes al extremo oriente) in 1918. Miguel Serrano, who was posted in India as the Ambassador of Chile from 1953 to 1962, explored Hindu mysticism. Considered as one of the most important occult fascists of the Spanish speaking world (Gardell, 2003), D'Halmar was a diplomat, who came close to prominent Indian figures of his time such as Jawaharlal Nehru, Indira Gandhi, Dalai Lama and Jiddu Krishnamurti. This might have given him ample scope to see India at close quarters. His book La Serpiente del Paraíso, published in 1963, is an account of his experience in India.

Apart from Miguel Serrano and Augusto D'Halmar, there have been a few more Chilean intellectuals who traveled, stayed and wrote about India. Francisco Coloane, Julio Barrenechea and Juan Marín have contributed immensely in their own rights, however, they are less studied thus far for this purpose. The Chilean Roberto Bolaño who wrote the famous novels, Savage Detectives (1998) and 2666 (2004) takes the protagonist from his short story "El Ojo Silva" published in Putas Asesinas (2001) to an unnamed Indian city and centers majority of the plot on an incident that occurr there due to certain religious practices of that city. Very much like Mistral, he never visited India. His Indian experience is rooted in his deep understanding of the subject. However, the Indian experience is, many a time, confronted with the experience in his Patria, Chile and neighboring countries, and yet the story evokes very strong imagery of India,

It seems appropriate to say that Latin American scholars included India as a thematic in their works in order to transcend the prosaic specifics of the Western worldview. In the present research work, we attempt to undertake a comprehensive study and analysis of two works by Julio Barrenechea namely Sol de la India (1969) and La India no misteriosa (1982). While the former is a collection of poems, the latter published posthumously and written on India, is based on the author's experience during his stay as the Ambassador of Chile in the 60s, for a period of almost seven years (1965-1971). The present paper examines the representation of India in these works of the author. We would attempt to locate his works within and outside Latin America, mainly with respect to the prevalent styles of European narrative representations. Barrenchea's stay in India 
for seven years made him familiar with aspects of Indian culture. To understand the traditions of India he filled his work Sol de la India with costumbrismo, a 19th century Latin American characteristic. He subdivided this work in a very costumbrista fashion. Barrenechea occasionally resorts to a structuralist lens and takes a binary position to understand and write about India. Nevertheless, his orientalism is varied from the European one as it allows him to engage with his Latin American self during the process. It has been observed as self-orientalism by Julia Kushigian (1991) in context of Octavio Paz' engagement with the Orient in his poetics. The present paper attempts to answer the following questions while reading and contextualizing Barrenechea's poetry and prose within Chilean scholarship on India;

- What is the thematic of Barrenechea's works on India?

- What is the significance of India in his literary trajectory?

\section{Theoretical framework}

Kate Marsh (2009) in her work affirms that travel writings on India by Europeans can be seen as a creation of a 'domestic subject for consumption' (p. 24). She further asserts that the tropes that Europe etches out of India are that of a feminine self, fakirs, Brahmins, reincarnation, caste system and sexual availability that set it apart from the Saidian interpretation of Orient. However, it is still a latent kind of Orientalism, owing it to the imagery of India in European narratives that is of an antithetical exotic against the civilized Europe.

Latin American travel writings are unique as they do not claim ownership as a result of their neo-colonial experience. European travelers have often claimed a sense of ownership over the representation of the "Other". Edward Said in his book Orientalism (1978) discusses in detail the patronizing attitude of the Western scholarship of the East. For Latin Americans, travel beyond their land adds to the unique neo-colonial experience, unlike the European Orientalist worldview.

Nevertheless, Julia Kushigian (1991) summarizes, "Significantly, Hispanic Orientalism also pursues an oppositional relationship between subject and object, but not for the purpose of denying the Other" (p. 103). Upon analyzing Borges', Paz' and Sarduy's engagement with the Orient she has drawn that the Hispanic Orientalism owes it primarily to the Convivencia of the Middles Ages in Spain when Christians, Muslims and Jews lived together and influenced each other linguistically, culturally and aesthetically. She has seen Latin American Orientalism as an extension to it and has concluded that "Hispanic Orientalism does not present the Oriental society as static and reactionary, incapable of inspiring others philosophically or aesthetically" (p.109).

Mary Louise Pratt has discussed at length in her work Imperial Eyes (1992) the understanding of travel writings in the context of Latin America, and mentions, "The neocolonial experience is marked above all as a difference of authority, a difference in what is entitled to claim to know about others" (p. 227). On the same line, she further suggests that it is a decolonizing optic that a Latin American intellectual develops, thus making a destination home for the self since "travel is a code that expresses the neo-colonial relationship" (p. 229).

Louise Pratt asserts in the same book that how can Latin America that has been seen as a destination for others turn into a home for the self? She discusses it through the trope of Macondo 
that is both a destination as well as a receptor. Macondo does not only tell a tale of the Buendías but also is as a motif for the European engagement with Latin America. A destination for others has become a home for Latin Americans. This is a very unique experience of Latin America, a neocolonial experience that allows them to engage with the self. She says, "this working through is a distinctive, energizing aspect of Latin American modernisms. Often it appears as a crisis of belonging, expressed in terms of travel." (p.227)

Contextualizing the unique neo-colonial experience of Latin America that is reflected in the works on India by Julio Barrenechea, one tends to revisit what Edward Said has elaborated in Orientalism (1978),

"Everyone who writes about the Orient must locate himself vis-à-vis the Orient; translated into his text, this location includes the kind of narrative voice he adopts, the type of structure he builds, the kinds of images, motifs that circulate in his text - all of which add up to deliberate ways of addressing the reader, containing the Orient, and finally, representing it or speaking in its behalf" (p.20).

One notes here that varied accounts on India documented by Latin American scholars are told like a story where the narrator seems to be homodiegetic; they participate as a character in the story of India that they describe rather than narrating it as its protagonist, contrary to the case of an autodiegetic narrator observed in a majority of the European accounts on India. The narrative structure often appears very graphic in the Latin American scholarship on India that can be witnessed through the images and the motifs that are evoked in these works. These images are represented within the Indian context seen through a lens made up of the neo-colonial experience of Latin America.

One intends to explore here that how the conscious use of costumbrismo in his works on India has enabled Barrenechea to participate as a character in the narrative, thus bringing about the unique neo-colonial experience of his Latin American self in his travel writings. This has been mentioned above following Mary Louise Pratt's ideas in her book Imperial Eyes.

\section{Life of Barrenechea}

Born in Santiago in 1910 to Julio Barrenechea Contreras and Claudina Pino Salazar, Julio Barrenechea was a writer, diplomat and politician. He started writing at an early age of 15 years and his first piece of work titled El mitin de las mariposas came out in 1930. In an interview he mentioned that he started writing because of his vocation and got motivated by his father in his earlier days. He participated actively in student's politics since he was young. In 1929, he organized a student movement in opposition to the government of General Carlos Ibáñez del Campo, for which he was confined to La Serena in 1931. A year later, he was elected as the President of the Chilean Student Federation that he continued for two consecutive terms. He was also a vocal critic of the Nazis, being one of the first voices in the Chilean Parliament to denounce the danger of Nazism in Chile.

Barrenechea accepted the honorable post of Ambassador in Colombia, remaining there for seven years, from 1945 to 1952. During his tenure, he gave asylum to a Colombian revolutionary, Saúl Fajardo. The Chilean government asked him to hand over Saúl to the 
5 | A Kaleidoscopic Gaze of India through Julio Barrenechea's oeuvre

Colombian government. He resigned from office rather than obeying the order for which he is still remembered in Colombia. He also served as the President of the Society of Writers of Chile. On September 14, 1960, he was conferred upon the National Prize for literature of Chile, contesting it among six great national poets. He was also nominated for Miguel de Cervantes Literary Prize in 1978.

Between 1965 and 1971, he served as the Ambassador of Chile to India. He carried out a very productive exercise of cultural dissemination during his term. Obsessed since his youth with the idea of death, he dealt with this topic in different ways in most of his poetry books.Sol de la India published in 1969 by Caxton Press (New Delhi) is the culmination of this idea. Two more literary works written during his stay in India were Ceniza viva (1968) and Estados de ánimo (1971). In 1965, his son died which left a profound mark on his philosophical understanding and subsequently on his literary creations. In his works, one can find the melancholic tone owing to this loss that he endured after he arrived in India. He was a member of the Chilean Academy of Language. He knew how to narrate in depth all that was his own, the one that he enjoyed and suffered. Those things that were part of his existence - land, friendship, objects, love and death do not only find a place as a thematic in his poetic work but also in his prose.

Each verse of Sol de la India allows one to delve into the mysteries of India that Barrenechea knew how to capture in all his humanity. The setting of Sol de la India is exotic, having a universal character, that was a result of his existential concern. Valdebenito (1983) in his commentary on the book la India no misteriosa wrote that Barrenechea has achieved faithfully to describe with friendliness and sympathy the spiritual greatness, social issues, customs, and beauty of India.

In one of the interviews in 1966, just after his assignment in India, when asked about his opinion on this Land of Gandhi and Nehru, he remarked that he did not have a "full vision of it" so far due to the overwhelming geographical extension and complex reality. He further added that he was trying to understand the nation wherein coexists modern developing India along with its fascination, mysteries, religion and the attitude of its people towards life. He pointed out that he had started to intellectually engage with the Indian writers and poets but their company was difficult due to idiomatic reasons.

Barrenechea tried to break the unilateral image of India through his literary works. For him, apart from India with all her mysteries, there exists an India with struggling lives and aspirations of a common person. Therefore, one can find in his literary works a mixture of "metaphysical contemplation" (Sequeira, 2018) together with the realities of common mass. The two literary works, which have been discussed in the present paper also somehow, show the author's preoccupation to demystify and reflect the image of unmysterious India.

\section{Sol de la India: Poetic Musings}

In Barrenechea's Sol de la India, one day seems to be one life. One can notice past, present and future gathering at one juncture in some of his poems in Sol de la India. While he was in India, his son passed away in 1965. Death occupied the center stage in his poems since then. Nevertheless, 
we can find the classical literary motif of locus amoenus in his poems that are marked with contradictions and juxtapositions like in the works of Paz.

This literary work has three thematic divisions: Festival (Festival), Más allá (Further), and Voz Cantante (Singing Voice). The first thematic division has eight poems, the second and third groups contain seven each, totaling twenty-two poems through which the poet tries to capture the image of India. The first reading of the poems and the titles suggest that this poetic work is a reflection of the sensibilities of the poet. Eliot (1957) referred to Barrenechea's poetry as expressive findings having both the metaphor and tone. Enrique Anderson Imbert, an eminent critic, as cited in Dey (1971), while referring to the author's works remarked, "Julio Barrenechea sings in a voice, which is serious, slow, at times melancholy, but always deep."

Sol de la India is a classic example of the amalgamation of narrative in the lyrics. Dey (1971) mentions that this poetic work merges the poet's personal encounters with India and his poetic attitude gives a narrative tone to this literary work. Barrenechea starts writing the poems in a very costumbrista fashion; giving us details of everyday life. In the first theme, one can appreciate the vivid description of customs, traditions, and festivals such as Diwali and Holi like in La Fiesta de las Luces (Festival of Lights), he writes:

Una tiza brillante dibuja a la ciudad,

en la pizarra de la obscuridad.

La línea de luz sigue

el perfil de las torres.

La frente de las casas,

el marco de las puertas y ventanas.
A bright chalk describes the city, on the blackboard of darkness.

The line of light follows

the profile of the towers.

The front of the houses,

the frame of the doors and windows.

In the present example, the use of la línea de luz (the line of light) brings about the exactitude of the decoration done in houses during the festival of lights, Diwali. He even talks about the people of India through some of his poems such as in La Fiesta del Color (Festival of Colours).

Holi ! Holi !

Todo es color,

y el juego de la gente sencilla

crea un mundo de maravilla,

Los amigos se cambian

amables pinturas

y con ello cambian

sus propias figuras.
Holi! Holi!

All around it is colourful, and the game of simple people creates a world of marvels, Friends turn themselves into lovely paintings and with them they change their own self.

One gets to look at the lives of the people celebrating the festival of colors at very close quarters through this poem, such as the adjective sencilla (simple) is used for the people playing with the colors. Nevertheless, one reads further only to observe that his poetics on India gradually 
becomes somber from being vivid, surreal from being costumbrista, and philosophical from being mundane as can be observed through the following poem:

Sol de la India
como ninguno,
tú eres la escencia,
tú eres el nudo.
Tú eres la vista
recuperada
de una pupila
que está extasiada.
Sol de la India,
razón de vida,
muero en las tardes
con tu partida

Sol de la India

como ninguno,

tú eres el nudo.

Tú eres la vista

recuperada

de una pupila

que está extasiada.

Sol de la India,

razón de vida,

con tu partida

Sun of India

like none,

you are the essence,

you are the knot.

You are the glance

recovered

from a pupil

that is extinguished.

Sun of India,

reason of life,

I die in the evenings

when you set.

The change in the thematic of his poems also aligns with the trajectory of his days in India at a personal level that is seen through the sufferings, which he had endured due to the loss of his family members as seen in the poem in question; it ends with the verse muero en las tardes con tu partida (I die in the evenings when you set.)

His poems do not only allow the readers to look at India superficially but also gaze deep into its spirit. Whilst he talks about the festivals and provides us with the mundane description of the festival of lights i.e. Diwali, he also underlines the class system prevailing in India as one can perceive in the example below that he talks about the most humble ones of the society celebrating the festival i.e. hasta los más humildes. Through this poem he also attempts to talk about Hinduism and his understanding of it as a faith rather than religion as he doesn't explicitly mention names of any gods or any complicated rituals but just su pequeña llama (a little flame for her) in the poem on Diwali, contrary to how has it always been understood when looked at through the western prism.

Por eso todos, todos,

hasta los más humildes,

los que más tienen que pedirle, como una temblorosa voz que clama, le encienden su pequeña llama.
That's why, all, everyone, even the most humble ones, those who even have to beg for it, like a trembling voice that reclaims, they light a little flame for her.

In the same collection of poetry Sol de la India, he includes verses on Hindu, Sikh as well as Muslim heritage/traditions such as the poems on Hindu festivals, on the sword of the Sikhs, and on the Mughal king Akbar. The imagery and the graphic description that Barrenechea etches out through his poems also show the true spirit of the place called India that strikes out in the world due to its motto of "unity in diversity". The coexistence that Barrenechea portrays poetically has almost become identical to India in the due course of time. Many Latin American travel 
writings have dealt with the theme of multiple in singular by portraying a myriad of hues that India is made-up of.

In the poem Boda (Wedding), he begins with talking about the bride and groom and the festive spirit but the mundane gradually gets mixed with the mysterious that it almost evokes the divine without rejecting the prosaic. Here the way he writes about the union of bride and groom by using the words such as aclarándose un misterio (revealing a mystery), it almost appears that Barrenechea begins to understand the soul of a mystic.

Aquí se junta la pareja

como aclarándose un misterio,

y frente a la espectante novia

se levanta el tupido velo.
It is here that the couple unites

As if revealing a mystery

and in front of the anxious bride

the thick veil is removed.

In his poems, it appears that the mundane is the divine and that the divine lives within the mundane, like the city of Benaras and the holy dip into the river Ganga that he has etched through his poem Benarés.

\begin{abstract}
El baño no es desplazamiento,
es éxtasis, con signos y ritos.

Cada cual crea una manera

de hallarse con el infinito.
\end{abstract}

The holy dip is not a displacement, it is ecstasy, with signs and rituals. Each one creates a way to meet infinity.

It appears to us on some occasions that while seeing the divine within the mundane, Barrenechea has used the Saidian prism of Orientalism by taking the established images of India into account as a basis of his analysis, but he has never come across as an intellectual, attempting to reject India or has found it contrary to the western notions as opposed to what has often been done by the European intellectuals who have written on India. Although he talks about the holy dip in context of Benaras, an image of the city that has become hackneyed; he tries to understand it within its own context and does not take this image out of it, only to avoid the absurdity that it might suggest if done so.

In Barrenechea, one finds the element of death in some of his poems. Sequeira (2018) points out that the experience of the poet in India "became a way of better understanding death, through its contrast with the world of appearances." One of the reasons for the darkness in this poetic collection is the loss in his personal life. Julio Barrenechea has suffered painful moments of regret, such as the suicide of his son Alfonso, on October 27, 1965, in New Delhi, when he was not yet 18 years old. Again in 1966, his Jewish wife Jaia Dyvinetz disappeared in Santiago in tragic circumstances. These events left the poet with a profound melancholy, which can be found in his poetic verses. In this collection of poems, he synthesized his obsession with death, a leitmotif present in all his poetic repertoire. The thematic reflection of death and melancholy is present in some of his poems in the second part of this poetic collection. In Casas para morir (Houses for Death) and Cementerio de Agra (Cemetery of Agra), one can see how the poet deals with the idea of mortality when he writes: 
Nunca he visto tan hondos los ojos de la muerte,

Como el viejo cementerio de Agra.

Que abandono, que olvido, que huida del recuerdo.

¡Como la piedra roja se va volviendo negra!
I have never seen the eyes of death going so deep,

Like the old Agra cemetery.

What abandonment, what forgetful-ness, what an escape from memory.

As the red stone is turning black!

In the last part, on one hand, the poet reflects upon the generic ideas of El Pueblo in Canto a las Manos Indias (Singing to the Indian Hands) and Las Mujeres (Women) of India, and on the other, he talks about his visit to Kashmir, Goa and Kolkata. He compared Kashmir to the south of Chile and this act of recognizing acquainted places represents "both a concession that individual places are not unique and a claim to his own territory" (Sequeira, 2018). He writes:

Amo esta tierra hermana de mi tierra, el rostro de mi sur lo veo en ella.

Los pinares, los lagos, y las nieves eternas,

...Enorme, verde espejo,

donde el sur de mi tierra se mira desde lejos.
I love this sister land of my land, I see the face of my south in her.

The pine forests, the lakes, and the eternal snows,

...... Enormous, green mirror, where the south of my land can be seen from afar.

Barrenechea always wanted to understand and comprehend the common psyche of the Indians and their attitude to life. Through his poems, he tried to manifest the collective philosophy of common Indian mass reflecting upon them critically. The first reading of the poem reflects a modest impression of the poet about the traditions, customs and imageries of different spaces in India, but a careful analysis and his earlier literary works suggest the poet's receptivity and multifaceted reflections on the complex realities of India.

\section{La India no misteriosa: A Demystifying Endeavor}

Barrenechea's literary work La India no misteriosa was published posthumously in 1982 in Chile. This is humorous prose, which describes the experience during his sojourn in India with Indian society and culture. Laborde (2002) in his biography points out that this book reveals the immense pleasure of the poet in describing other geographical landscapes, other races and customs, the inexhaustible diversity of the human. For Barrenechea, this is a direct and essential India, an India with cities, rivers and forests, an India with people that believes, works, hopes, loves and lives like any other people in the world. He even criticized the tourists who proclaimed to be an expert on this land after staying here for a few days and presented a fantasy, which was far from the truth. He said,

"...la India que me salió al encuentro. Esa realidad perceptible después de casi siete años de residencia en aquel país. Es decir, en aquel continente. ...Sólo deseo dejar en claro que en ese pais, al cual se estima como exclusivamente espiritual, existen también todos los 
defectos materialistas de que sufren los países de la tierra. Lo cual, por supuesto, no excluye el reconocimiento de sus virtudes". (1982, p.10)

("...the India that met me. That perceptible reality after almost seven years of stay in that country. That is, in that continent. ...I only wish to make it clear that in that country, which is considered to be exclusively spiritual, there are also all the materialistic defects from which the countries of the earth suffer, which, of course, does not exclude the recognition of its virtues.")

In this way, the Chilean gaze of Barrenechea was in contrast with that of his predecessor Miguel Serrano whose Indian experience primarily focused on the spirituality of this land, on its saints and gurus. On the other hand, Barrenechea took a different position and showed India as a nation like any other "Third world" nation as he referred to India as "la cabeza del Tercer Mundo" $(1982$, p.9)

Arenas (1982) indicates in context of La India no misteriosa what Barrenechea was mostly known for, "his sense of humor, his exactness in the sentence and his foray into the depth of reality, but from which he returns almost immediately to account for the result". At the beginning of the prose, he shows his understanding of the Indian culture when he humorously mentions his credential presenting ceremony and his presentation speech phonetically transcribed because of his little knowledge of the English language. He gave an example of the faro (beacon) and tocino (bacon) to highlight the cultural understanding and how the use of the word "bacon" could have caused uneasiness for both Hindu as well as Muslim communities.

One can find that on one hand, Barrenechea talks about the caste system, giving examples from the supporting staff members from the embassy and on the other, touches upon the love of mothers towards their offspring. He said,

"el servicio obedece rigurosamente a la división de castas. Hay varios servidores para un solo servicio, pues la diversificación de funciones determina aquella división" (1982, p.25).

(The service strictly obeys the division of castes. There are several attenders/servants for a single service since the diversification of functions determine that division).

In the same line, he described the job functions according to the caste hierarchy, which was unique for a Chilean to understand at that point in time. He used the local words in Hindi to describe each of the jobs one was performing in the embassy, like chaprassi (peon), ayah (nursemaid), chowkidar (security guard), dhobi (washerman) etc. These lexical choices may reflect his engagement with the local Indian culture.

The book continues with various descriptions of the customs of India. Thus one reads that Hindu dance is not an attempt to entertain an audience (as is often the case in the West), but is performed to communicate with the deity. He has reflected upon the religiosity of the Indians, something that often overwhelmed him. In this sense, one can appreciate the image that was generated of the Indian people, more specifically of the Hindus.

"me formé la impresión de que los hindúes son muy supersticiosos o sienten temor ante sus muertos. Los Iloran extraordinariamente. Me parecía algo contradictorio este hecho, 
dada la seguridad que su religión le da en la existencia de otra vida. Creen en el más allá, pero son muy apegados al más acá" (1982, p.20)

(I got the impression that Hindus are very superstitious or fearful of their dead. They mourn them extraordinarily. I found this fact somewhat contradictory, given the certainty that their religion gives them in the existence of another life. They believe in the afterlife, but they are very attached to the hereafter.)

However, he wrote later in the prose declaring and confessing his love towards them. He always wanted to extract the common philosophy of life and he said:

"debo confesar en voz muy alta mi amor por el pueblo hindú, por los pobres de India. Siempre traté de entenderlos, de comprender a esa gran masa oscura y anónima, expuesta a las más violen-tas expresiones de la naturaleza. Quise extraer de ella una filosofía común, es decir, una actitud ante la vida" (1982, p.49)

(I must confess in a loud voice my love for the Hindu people, for the poor of India. I have always tried to understand them, to understand that great dark and anonymous mass, exposed to the most violent expressions of nature. I wanted to draw from them a common philosophy, that is to say, an attitude towards life.)

In the same line, like many other western writers, Barrenechea tried to understand the religious connotations of the cows, but he presented the vision of the Indians on the subject without judging it.

"durante los casi siete años que permanecí en India no pude aclarar, de manera satisfactoria para mí, el misterio de las vacas sagradas...Los occidentales se extrañan que pueda haber hambre en India en circunstancias de que se desprecia la posibilidad de consumir doscientos millones de va-cas. Pero, para el hindú, la vaca no es alimento: comerla constituiría algo así como un acto de antropofagia: podrían, debido a su creencia en la transmigración, ......." (1982, p. 72-73)

(During the almost seven years that I stayed in India, I could not clarify, in a satisfactory way for me, the mystery of the sacred cows... Westerners are surprised that there could be hunger in India in circumstances in which the possibility of consuming two hundred million cows is scorned. But, for the Hindu, the cow is not food: eating it would constitute something like an act of anthropophagy: they might, because of their belief in transmigration.......)

As the name of the book suggests, through this work Barrenechea has tried to break the so-called "mysterious" image of India. Arenas (1982) in his analysis expressed that the title of this piece is "already a whole program". In a way, he has tried to portray an image, which was distinct from the past image that was more oriented to show the mysterious and millenary India, as was the case in European orientalist representation of India. He described other local realities taking examples from daily life much beyond the mystery. In a way, Barrenechea wanted to show India suffering from the same materialistic defects that all the countries of the earth suffer.

This portrayal of the image of India was different from the exoticism and fantasy for which India was known to the western world, especially Chile at that point in time. This may be partly 
because of his political engagement as Ambassador of Chile. It was during this time that Indira Gandhi, Prime Minister of India, made the first official visit to Latin America in 1968, which paved the way further towards defining India-Chile bilateral relations.

\section{Discussion and conclusion}

The poetic collection Sol de la India deals with a host of themes included as a form of different poems in this work. One observes that the thematic, however, is not only mediated through the European lens but Barrenechea's gaze of India is through a kaleidoscope where he can see vivid hues of a culture. From colorful depictions to somber, from surreal to mundane, his India is unique but not a singularity. His poems on various aspects of India create an imagery with a co-existence of paradoxes that are, nonetheless, yet very much interconnected to each other.

Based on the two works studied carefully, one sees that the thematic of his works is a depiction of the everyday reality of India, yet not reducing it to mundane. In Sol de la India, he does so by occasional philosophizing about festivals, customs, traditions, faith, life and death in the same collection of poems.

In La India no misteriosa, he clearly breaks the prevailing unilateral image of India, especially in Chile. The title of this work suggests it is an attempt to demystify the prevalent image of India. From pointing out what overwhelms him about Hindus to recognizing the philosophy of life in Hinduism, he has captured through this work.

With regard to the significance of India in Barrenechea's literary trajectory, we believe that India acts as a metaphor for his inner sentiments, for the personal loss that he suffered in his life. Sol de la India is considered as the culmination of such expression that deals with death as a recurring motif, as if the poet is trying to simplify his complex emotions. Nonetheless, during this process, he never claims any ownership on India thus making it a unique representation that he seemingly draws from the neo-colonial experience of his Patria.

Barrenechea's poetry has always been distinguished by its simplicity and harmony and is marked with the spontaneous communication of emotions and his lyrical ideas. These formal characteristics are found in Sol de la India too. The readers can feel the rhymes, the rhythms and the depth of the thematic in the poem, built on the premises of his personal experiences with the Indian realities. The humor and sarcasm are present in his prose keeping in mind the socio-cultural nuances with authentic touch, and without artifice. The two literary works in the present study reflect critically how India left a perennial mark in the intellectual engagement of this Chilean writer of the twentieth century.

The writings of Barrenechea have proved to be an attempt to understand India through poems as well as prose with a unique neo-colonial experience of a Latin American self. Writing in his costumbrista style about the everyday reality of Indian people to extracting the deep philosophical meaning of life from the religious practices appear to provide him with a kaleidoscope that he has used to look at and describe the vivid hues of India through his works.

\section{Acknowledgement}


21 | A Kaleidoscopic Gaze of India through Julio Barrenechea's oeuvre

The author(s) received no financial support for the research, authorship, and/or publication of this article.

\section{Declaration of conflicting interests}

The Authors declare that there is no conflict of interest.

Note: The authors have carried out the translations of the poems and texts in the paper.

\section{References}

Arenas, Braulio. (1982, October 3). La India no misteriosa. El Mercurio. Available in National Library of Chile http://www.memoriachilena.gob.cl/602/w3-article-98517.html. Accessed on 9 July 2020.

Barrenechea, Julio. (1930). El mitin de las mariposas: poemas. Santiago: Editorial Minarete.

Barrenechea, Julio. (1966). Recuerdos de la India voz de su autor: Julio Barrenechea. Available in http://www.bibliotecanacionaldigital.gob.cl/visor/BND:152926. Accessed on 18 July 2020.

Barrenechea, Julio. (1968). Ceniza viva. Madrid: Cultura Hispánica.

Barrenechea, Julio. (1969). Sol de la India. New Delhi: Caxton Press.

Barrenechea, Julio. (1971). Estados de ánimo. Madrid: La Muralla.

Barrenechea, Julio. (1983). La india no misteriosa. Santiago: Andrés Bello.

Bolaño, Roberto. (1998). Los detectives salvajes. Barcelona: Edit. Anagrama.

Bolaño, Roberto. (2001). Putas asesinas. Barcelona: Editorial Anagrama.

Bolaño, Roberto. (2004). 2666. Barcelona: Editorial Anagrama.

Dey, Susnigdha (1971). A Latin American Poet's Vision of India. Indian Literature, 14 (1), 106-111. https://doi.org/10.2307/23330568

d'Halmar, Augusto. (1918). Nirvana. Viajes al Extremo Oriente, $1^{\text {a }}$ ed. Barcelona: Casa Editorial Maucci.

Eliot, Jorge. (1957). Antología Crítica de la Nueva Poesía Chilena. Consejo de Investigaciones de La Universidad De Concepción: Concepción. https://www.neruda.uchile.cl/critica/jeliot.html

Gardell, Matthias. (2003). Gods of the Blood: The Pagan Revival and White Separatism. Durhan and London: Duke University Press.

Gómez, C. (2011). De la India a las Indias y viceversa: Relaciones literarias entre Hispanoamérica y Asia (siglo XX). Iberoamericana (2001-), 11(42), 43-63. http://www.jstor.org/stable/41677366

Marsh, Kate. (2009). India in the French Imagination: Peripheral Voices. London: Pickering \& Chatto.

Kushigian, Julia. (1991). Orientalism in the Hispanic Literary Tradition: In Dialogue with Borges, Paz and Sarduy. Albuquerque: University of New Mexico Press.

Laborde, Miguel. (2002). Contra Mi Voluntad, Biografía de Julio Barrenechea. Santiago: RIL Editors

Neruda, Pablo. (1924). Veinte poemas de amor y una canción desesperada. Santiago: Nascimento, 
Pratt, Mary Louise. (1992). Imperial Eyes: Travel Writing and Transculturation. London: Routledge.

Said, Edward W. (1978). Orientalism. Pantheon Books.

Sequeira, Jessica. (2018, July 23). Like Shadows, Like Clouds. https://www.berfrois.com/2018/07/jessicasequeira-julio-barrenechea-in-india/. Accessed on 25 June 2020.

Serrano, Miguel. (1963). La serpiente del paraíso. Santiago de Chile: Nascimento

Valdebenito, W. R. (1983). Julio Barrenechea: "La India no misteriosa". Renacer de Chile. Available in National Library of Chile http://www.bibliotecanacionaldigital.gob.cl/bnd/628/w3-article-277269.html. Accessed on 13 July 2020.

Dr Mala Shikha is Assistant Professor in the Department of Spanish Studies, Doon University, Dehradun, India.

Dr Ranjeeva Ranjan is Assistant Professor in the Faculty of Education, Universidad Católica del Maule, Talca, Chile. 